Boise State University

ScholarWorks

Literacy, Language, and Culture Faculty

Publications and Presentations

Department of Literacy, Language, and Culture

$1-2019$

\title{
A Validation Program for the Self-Beliefs, Writing-Beliefs, and Attitude Survey: A Measure of Adolescents' Motivation Toward Writing
}

Katherine Landau Wright

Boise State University

Tracey S. Hodges

University of Alabama

Erin M. McTigue

University of Stavanger

Publication Information

Wright, Katherine Landau; Hodges, Tracey S.; and McTigue, Erin M. (2019). "A Validation Program for the Self-Beliefs, Writing-Beliefs, and Attitude Survey: A Measure of Adolescents' Motivation Toward Writing". Assessing Writing, 39, 64-78. https://doi.org/10.1016/j.asw.2018.12.004

This is an author-produced, peer-reviewed version of this article. (C) 2019, Elsevier. Licensed under the Creative Commons Attribution-NonCommercial-NoDerivs 4.0 license. The final, definitive version of this document can be found online at Assessing Writing, doi: 10.1016/j.asw.2018.12.004 
RUNNING HEAD: A Validation Program for the Self-Beliefs, Writing-Beliefs, and Attitude Survey

A validation program for the Self-Beliefs, Writing-Beliefs, and Attitude Survey: A measure of adolescents' motivation toward writing 


\begin{abstract}
Recent findings reveal clear evidence that students’ low performance on writing tasks is often related to problems with motivation. Writing curriculum and interventions produce varying effects on adolescents' writing outcomes, and such variations may be mediated by motivation. However, without a valid tool for measuring students' motivation towards writing, these effects cannot be quantified. In this study we present the results of our multi-study validation program for the Self-Beliefs, Writing-Beliefs, and Attitude Survey (SWAS). This measure is designed for monitoring students' motivation towards writing, as well as identifying variables that mediate student achievement. We first addressed substantive validation through a thorough review of research. Next, in Study 1, we established structural validity through multiple types of factor analyses and establishing reliability coefficients for the instrument scores. Finally, in Study 2, we provide evidence of external validity by comparing students' SWAS scores to other measures of writing. Following these procedures, we were able to establish that the SWAS provides a valid measure of students’ writing motivation and is an instrument appropriate for a particularly important age group - adolescent learners. Additionally, through this process, we add to the theoretical base by proposing a new multi-dimensional model of writing motivation.
\end{abstract} Keywords: Writing; motivation; adolescents; assessment; validation 


\section{Introduction}

Teachers acknowledge that typical writing instruction for adolescents may not always inspire motivation (Troia \& Maddox, 2004). In early grades, although instruction focuses primarily on mechanics, students are often allowed to write on topics of their choice (Katz \& Assor, 2007). However, by middle school, writing autonomy diminishes as the focus shifts and students are required to produce discipline-specific texts. At the same time, in secondary grades, most students complete little extended or complex writing allowing minimal opportunity for creativity and expression (Applebee \& Langer, 2009; Graham \& Harris, 2012). This situation has contributed to $74 \%$ of $8^{\text {th }}$ graders and $73 \%$ of 12 graders scoring at the "basic" or "below basic" level on national writing tests. We maintain that writing instruction that does not emphasize motivation may be contributing to students’ low performance (NCES, 2012).

Researchers are still exploring what motivates adolescents to write, but recent findings reveal clear evidence that students’ performance on writing tasks is related to motivation (Zumbrunn, Marrs, \& Mewborn, 2016). As motivation for writing can vary depending upon the situation and task, teachers and scholars require valid assessments to determine whether writing skills are primarily a result of cognitive ability and knowledge, affective issues (e.g., motivation), or both. If students are not motivated to write, they may be viewed as having poor writing skills, even if this is not true (Johnston \& Costello, 2005). Being identified as having underdeveloped skills may place students on a trajectory of specific coursework and lowered expectations. However, without a valid tool for measuring students' motivation towards writing, these effects cannot be quantified.

Researchers also know that writing instruction and interventions have varying effects on adolescents’ outcomes (Graham \& Perin, 2007; Washburn, Sielaff, \& Golden, 2016), which are 
likely mediated by motivation. For example, Webb, Vandiver, and Jeung (2016) found that a course focused on developing the writing process supported students' self-efficacy for writing better than courses focused creative or analytical writing. As such, a deeper understanding of adolescent students' writing affect, in the context of educational interventions, will help identify practices that produce gains in skills while preventing (or reversing) the development of negative self-concepts. Furthermore, a child who has had negative experiences with writing will likely develop a poor attitude toward that experience (Fishbein \& Ajzen, 1975) and potentially believe there is great personal cost in engaging in the task (Eccles \& Wigfield, 2002). If we extrapolate these attitudes to writing, we can conclude that if a child has had negative experiences with writing, he or she may have a poor attitude toward writing and believe that writing has little value.

In this study we present the results of our two-study validation program for the SelfBeliefs, Writing-Beliefs, and Attitude Survey (SWAS). This measure is designed for monitoring students' motivation towards writing, as well as identify variables that mediate student achievement. To date, existing tools contain important limitations for measuring adolescent students’ affect towards writing. For example, select measures only consider one aspect of writing affect (e.g., Kear, Coffman, McKenna, \& Ambrosio, 2000), yet we know that motivation is a complex construct. Therefore, we worked to create a multidimensional instrument. Furthermore, other measures present relatively low reliability (e.g., Troia, Harbaugh, Shankland, Wolbers \& Lawrence, 2013). As reliability is an essential component of validity (Thompson, 2003), we enacted a multistep process for assessing reliability. Most importantly, few measures have undergone rigorous, multi-step validation programs to ensure their scores measure the intended writing constructs. 
Validation is a critical component of measurement development, because only through this process do scores take on meaning. Most contemporary researchers report statistical validity (such as factor analyses and/or structural equation modeling) and include reliability estimates (e.g., see Collie, Martin, \& Curwood, 2016; Troia et al., 2013). These are essential steps towards validation, but further work is required. Benson (1998) proposed that a strong validation program has three distinct components: the substantive, the structural, and the external. Substantive refers to the collection of existing theoretical and empirical information to define constructs, which we addressed through a thorough review of research. The structural piece entails determining how the observed variables relate to one another and the main construct of interest, so we conducted multiple types of factor analyses (Study 1). Finally, the external component requires the researcher to determine how the measure relates to other expected constructs (Benson, 1998), which we addressed by comparing students' SWAS scores to other measures of writing (Study 2).

Beyond instrument development, through the process of theoretical reviews and empirical validation, we aim to propose a model of writing motivation for adolescents. Specifically, we present the findings of two studies aimed at establishing the validity of the SWAS. Our research is guided by the following questions:

1. How valid are the constructs measured by the Self-Beliefs, Writing-Beliefs, and Attitude Survey?

2. What aspects of students' affect towards writing are measured by the Self-Beliefs, Writing-Beliefs, and Attitude Survey?

\section{Prior Research and Theoretical Foundations}


Writing is a skill that "allows people to communicate with others removed in both distance and time” (Graham \& Perin, 2007, p. 445). Furthermore, following the work of Myers and colleagues (2016) writing is conceptualized as a "complex cognitive, physical, affective, and social" process, requiring writers to "use multiple skills and strategies as they move through the stages of planning, drafting, revising, editing publishing, and presentation” (p. 312). Therefore, we define writing as the skills and affective variables that help people communicate, think critically, and make decisions about messages through the writing process.

Adolescent writers are simultaneously developing their personal identify while also better understanding their academic capabilities (Schaefer, Malu, \& Yoon, 2016), and writing can play a crucial role in that development (see, Graham \& Perin, 2007). Not only is writing important for academic success, but it can also lead adolescences to engage in a process of self-reflection and understanding (Pajares \& Valiante, 2006). Unfortunately, by the time students are completing middle school, research has shown that their value of and motivation for writing has decreased, which is concerning as students enter high school (Author, 2017; Clearly, 1996).

For teachers, balancing the students’ psychological and social needs with academic goals can seem overwhelming, especially when trying to improve students' writing (Zumbrunn et al., 2016). Yet, attention in this area can reap benefits for adolescents, as those with more positive views and motivation for writing often perform better on writing achievement measures (Graham, Kiuhara, Harris, \& Fishman, 2017; Villalón, Mateos, \& Cuevas, 2013). Middle school is a unique time in students' development as writers, yet current tools measuring writing motivation may not capture the full nuance of how students approach writing. Many factors contribute to students' motivation to write and their future success in schools. 
Motivation influences how students approach writing and how likely they are to persevere if the task becomes challenging (Bruning, \& Horn, 2000). More specifically, students with high self-efficacy for writing performed better on writing outcomes (Bruning, Dempsey, Kauffman, McKim, \& Zumbrunn, 2013; Locke \& Johnston, 2016). Perhaps one reason motivation is left out of writing curriculum is that it is a multifaceted construct that can be difficult to define. In the following section, we detail some of the challenges in defining what motivates someone to write.

\subsection{Challenges in Defining Writing Motivation}

It is important to note that writing motivation is a dynamic construct that can vary by discipline, situation, or developmental stage. Students’ beliefs about themselves as writers will likely vary across different writing tasks (Bruning \& Kauffman, 2016), and their motivation shifts over time as a result of various experience (Dörnyei, 2000). Specifically, current research emphasizes disciplinary literacy connections within content-specific classrooms (Shanahan \& Shanahan, 2008). From a disciplinary literacy perspective, writing motivation is tied to how students are taught to think, read, and write as experts within the field (Shanahan \& Shanahan, 2012). This approach also allows writing motivation and instruction to be more nuanced:

students may be motivated to write more in science than when writing poetry in English class. When students think with deep knowledge in specific fields, their level of writing motivation can vary depending on the task, content, and context (Gillis, 2014).

In addition to considering disciplinary literacy outcomes, research has also emphasized writing through a sociocultural lens, which is the leading theory for writing in education (see, Prior, 2006). Sociocultural theory posits that students learn writing based on motivation factors as well as the context, social expectations, and cultural norms (Author, 2017; Prior, 2006). In 
middle school, this theory explains how students' motivation may vary across grades, days, or school settings. For example, a student may enjoy writing at home when they choose to write, but may feel less motivated to write during class when they did not have full autonomy over the decision. Finally, sociocultural theory predicts that students are motivated when they are provided opportunities to share their writing, collaborate on writing tasks, and learn from more knowledgeable others in writing (Vygotsky, 1978)

In addition to contextual factors, writing motivation is difficult to describe with a single theoretical model because it is multifaceted. Motivation includes the internal and external forces that influence an individual's decision to engage in and persist through tasks. While there are many theoretical models to explain motivation, or, as Eccles puts it, why anyone does anything (Eccles \& Hulleman, 2017), they all demonstrate that motivation is complex, multifaceted (Deci, Vallerand, Pelletier, \& Ryan, 1991), and dependent upon the context and task at hand (Eccles \& Wigfield, 2002; Graham, 2018). Motivation to write is no exception.

Recently, Graham (2018) asserts that many existing models of writing ignore either the cognitive or sociocultural factors that impact writing achievement, while others have ignored “motivational resources writers bring to the task of writing” (Graham, 2018, p. 272). Therefore, we apply multiple theories of motivation to writing to capture these oft neglected dimensions. Specifically, we used Expectancy Value Theory (EVT, Eccles \& Wigfield, 2002) and Theory of Attitude (Fishbein \& Ajzen, 1975) to help explain how individuals’ identities as writers are developed, and how this impacts motivation. Beginning with the framework of interrelated motivational constructs proposed by Conradi, Jang, and McKenna (2014), we identified two broad categories of affective concepts that may influence a student's motivation to write: beliefs 
(i.e., Self-Beliefs and Writing Beliefs) and pre-dispositions (i.e., Attitude). In the following sections, we explore these two broad constructs in relation to the supporting theories.

\subsection{Theoretically-based Factors Affecting Writing Motivation.}

Two factors that influence why people may be motivated to engage in any activity are their beliefs related to and their pre-dispositions towards the task.

2.2.1 Beliefs. Eccles and Wigfield's (2002) Expectancy-Value Theory (EVT) posits that people engage in a task when they believe there is a value to it and that they have some chance at being successful. We describe these feelings as individuals’ beliefs about writing (i.e., Writing Beliefs) and about themselves as writers (i.e., Self-Beliefs).

2.2.1.1 Beliefs about writing. A student is unlikely to write if he or she does not consider it to have value. Conradi and colleagues (2014) define value in a task as the belief it "is generally useful, enjoyable, or otherwise important” (p. 155). For instance, an example survey question measuring value would be: I believe it is very important to be a good writer. However, it is important to remember that this value is subjective and that students will value writing for different reasons. Furthermore, Eccles and Wigfield (2002) suggest that many personal factors, including identity, self-concept, and goals, impact the value placed upon a task. Thus, we argue that researchers must examine student beliefs about writing, and how much they value being able to produce a quality-written product, to understand their motivation. For example, a survey may inquire: I don’t mind when my teacher asks me to go back and change some of my writing.

2.2.1.2 Beliefs about the self as a writer: Self-concept and self-efficacy. An individual's beliefs about themselves as writers also influence whether they choose to embrace the challenge of writing. According to EVT, simply believing that a task is valuable is not enough to spur engagement; one must also believe there is a reasonable chance at being successful (Eccles et al, 
1983). Reading researchers have differentiated these beliefs into two categories: Self-concept and self-efficacy. Yet the boundaries between these two constructs are often poorly defined, leading to the terms often being used interchangeably. Bong and Skaalvik (2003) address this confusion by arguing that self-concept is a "composite view of oneself" (p. 2) formed through experiences and comparisons with peers. For example, a self-concept item may query: When my class is asked to write an essay, report or story, mine is one of the best. Self-efficacy, in contrast, is focused on what an individual believes he or she can achieve with the skills and abilities they currently possess. Applying this to writing, Pajares (2003) posits that self-concept beliefs include “judgements of self-worth” (p.147) whereas self-efficacy is related to a specific skill or task. In short, self-concept tells someone they are, in general, a good writer, whereas self-efficacy tells them they have the skill-set to successfully complete a particularly difficult essay. As such a representative self-efficacy item would be: When I get a good grade on a paper, it is because I tried very hard.

Both self-concept and self-efficacy relate to academic motivation; however, they predict different outcomes. Previous research has demonstrated that self-efficacy can predict writing scores, even when controlling for other variables such as writing aptitude and previous grades (Pajares, 2003; 2007). Self-concept tends to predict affective reactions, whereas self-efficacy speaks to cognitive processes (Bong \& Skaalvik, 2003). For example, students with high selfconcept may feel good about completing a writing product. In contrast, students with high selfefficacy will likely view the process of writing more positively and acknowledge their strengths and areas of improvement more readily. Therefore, we hypothesize that together self-concept (as a writer) and self-efficacy (for writing) make unique contributions to beliefs about oneself as a writer. 
2.2.2 Pre-Dispositions. Conradi and colleagues (2014) identified pre-dispositions, including attitude, as a factor in the hierarchy of concepts likely impacting reading motivation. While sometimes confused with motivation, attitude describes prominent feelings and evaluative beliefs about a topic (Mathewson, 1994), such as a students’ opinion that: Writing can be a lot of fun. Pre-dispositions include the pre-existing attitudes and feelings students bring with them to the writing task. Unfortunately, in writing research, a clear definition of writing attitude remains elusive (Ekholm, Zumbrunn, \& DeBusk-Lane, 2017). Although attitude is a component of writing motivation, the latter tends to vary depending upon the context (Guthrie, Hoa, Wigfield, Tonks, \& Perencivich, 2006), whereas the former remains stable (McKenna, Conradi, Lawrence, Jang, \& Meyer, 2012).

Within writing research, scholars have found that students' motivation to write is highly influenced by attitude. For instance, one negative experience with writing may foster poor writing motivation that is challenging to combat (Hall, 2016). This reaction in writing is likely because writing is a productive activity rather than a receptive one, in which students create something new to be evaluated (Frankel, Becker, Rowe, \& Pearson, 2016). Thus, understanding students’ attitudes towards writing may help explain variation in writing motivation.

\subsection{Established Writing Affect Measures}

As part of the substantive stage of validation, we consulted many related tools (see Table 1). Despite the importance of affective factors related to writing, specific limitations exist in many published measures. For instance, Kear and colleagues (2000) published the Elementary Writing Attitude Survey, normed for students in first through $12^{\text {th }}$ grade. This measure asks students to indicate how certain statements about literacy would make them feel. However, the 
Elementary Writing Attitude Survey focuses solely on writing attitude, which does not capture the multi-dimensionality of other affective factors such as value or self-beliefs.

The Writing Activity and Motivation Scales (WAMS) (Troia et al., 2013) is a Likert-style questionnaire that has been administered to students in grades four through 10 . This 30 -item questionnaire measures six facets of writing motivation. The questionnaire also includes 10 items designed to measure how often students write in a month. The WAMS's theoretical model and measured constructs are similar to those of interest in the present study; the creators even argue that there is a need for a scale that honors the multidimensional nature of motivation. Unfortunately, the reliability estimates for many of the subscales were quite low (less than 0.60 in some instances), suggesting that items may not be measuring their intended construct (Troia et al., 2013).

Most recently, Collie and colleagues (2016) conducted a construct validation of a measure of writing motivation and engagement. These authors adapted existing measures of overall academic motivation to focus on writing, and asked participants to self-report recent results from a standardized literacy examination. Findings indicated that motivation and engagement factors were positively associated with literacy outcomes. While this research made great strides towards validating a multidimensional model of writing motivation, further work is still required. First, as the authors acknowledge, the nature of the literacy exam made it impossible to delineate between reading and writing achievement. Thus, the observed associations may be influenced by participants’ reading abilities. Secondly, while self-report achievement data is often highly associated with actual achievement (Hattie, 2009), it is still subject to Hawthorne effects (Thompson, 2006). 
While multiple tools measuring literacy and academic affect exist, we still need a valid measure specifically for adolescents' motivation towards writing. Therefore, this study aims to (1) measure multiple dimensions of writing motivation with strong validity, and (2) propose a model of writing motivation that aligns with current theories of motivation.

\section{SWAS Instrument Development \& Substantive Validation}

After examining existing tools for measuring writing affect, we selected the Motivation for Reading Questionnaire (MRQ) (Wigfield \& Guthrie, 1995) to provide an initial structure for our measure. While the MRQ does not pertain to writing, it provides a theoretically-supported model for assessing student motivation. This tool has been repeatedly used to measure students' (including adolescents) motivation towards reading, and consistently produces valid scores (e.g., Guthrie et al., 2006; Mason, 2004).

For individual item development, we referred to several existing instruments that measured aspects of reading, writing, or overall academic affect (see Table 1). We removed redundant items and those not be applicable to the present context, resulting in 41 possible items. Consistent with the MRQ, we constructed the survey to require students to rate each statement on a scale of 1 to 4 . Here, a 1 indicates that the item sentiment is "very different from me" and a 4 indicates that it is "a lot like me”. We intentionally avoided the option of a neutral response, as is the norm with literacy affect surveys (e.g., McKenna \& Kear, 1990; Wigfield \& Guthrie, 1995). Table 1 about here

\subsection{Substantive Validation}

To validate the theoretical underpinnings of the measure, we first qualitatively coded the survey items to identify what constructs we believed each to measure. We referred to Conradi 
and colleagues’ (2014) consensus definitions of motivational constructs to ensure we had common definitions. Working independently, each author coded the 41 items.

Following our independent coding, we found that at least two authors agreed on $75.6 \%$ ( $n$ =31). We discussed the remaining 10 items until consensus was reached. As a result of our deliberations, we tentatively coded three items related to interests, one to goals, five to selfefficacy, four to self-concept, one to agency, three to value, one to expectancy, and eight to attitude (see Appendix B). We organized these constructs in Conradi and colleagues' hierarchy under the headings of interests, goals, beliefs about self, beliefs about reading [writing], and attitude.

\section{Study 1: Structural Validation}

\subsection{Study 1 Methods}

4.1.1 Survey Administration. We administered the SWAS to 517 students at a public middle school (grades six through eight), in the southwestern United States. Students completed paper-based versions of the survey, and total administration took about 15 minutes. Teachers read the entire survey to students to ensure that results were not impacted by students' reading ability.

Both the university and local school-level Institutional Review Boards approved our plan to administer this survey without seeking parental permission if individual student data was limited to grade and gender. This allowed us to collect the large sample required for statistical validation; however, this was simultaneously constraining, as we could not analyze class-level data or collect information about individual students' race, linguistic, or socio-economic backgrounds. 
4.1.2 School Context \& Participants. The school represented a diverse sample of students. The majority (75\%) were eligible for free or reduced lunch, and approximately 10\% were identified as English Language Learners. This school housed the district's middle school gifted and talented programs, comprised of students performing above grade-level expectations. In total, approximately $65 \%$ of the students present provided assent and fully completed the survey (see Table 2).

Table 2 about here

4.1.3 Data Analysis Procedures. Following the instrument development protocol of Brackett, Reyes, Rivers, Elbertson, and Salovey (2012), we conducted the validity procedures by splitting the sample $(n=509)$ at random to conduct both exploratory (EFA) and confirmatory factor analyses (CFA). The EFA sample was used to find the psychometric model-of-best fit. Using the second half of the data set, we conducted multiple CFAs to compare our EFA findings with the theory-based model identified during the item coding procedures (described above). This enabled us to construct a model with strong psychometric and theoretical validity.

\subsection{Study 1 Results}

In the following sections, we first describe the EFA models and results. Next, we explain the results of our CFAs.

4.2.1 Exploratory Factor Analyses. The group of students was randomly split into two ( $n 1=258$ and $n 2=251$, respectively) using SPSS software. For the EFAs, we used the $n 1$ group. The Kaiser-Meyer-Olkin Measure of Sampling Adequacy (KMO) was 0.918, and the Bartlett sphericity test was less than 0.000 , indicating we could reject the null hypothesis (the items were not correlated) and proceed with a factor analysis. We conducted multiple Principal Components Analyses (PCA) with Promax rotation. We tested five EFA models to determine which best fit 
our data (see Table 3), starting with those based upon statistical results and moving to those based in theory.

Table 3 about here

For the final EFA model, we examined the items in each iteration and discovered that five items did not factor well in any model. These five were also items we had identified as theoretically ambiguous during coding. We therefore removed them and repeated the five factor EFA. The resulting model explained $55.94 \%$ of the total sample variance. Now consisting of 36 items, the SWAS yielded a Cronbach's $\alpha$ of 0.945 and McDonald's $\omega_{\mathrm{H}}$ of 0.900 (see Table 4). We detail the properties of the five factors in Table 4, and the structure coefficients for the included items in Appendix A.

Table 4 about here

4.2.2 Parallel Analysis. Table 5 provides the eigenvalues greater than one and the parallel analysis scores for each factor at the $95^{\text {th }}$ percentile. The first three factors have eigenvalues greater than the $95^{\text {th }}$ percentile scores for the parallel analysis. This indicates that the factors are significant and suggests that a three-factor model could be a better fit for the data. Table 5 about here

4.2.3 Higher-Order Factor Analysis. Because the model demonstrated correlation between the factors, we conducted a higher-order factor analysis. These procedures confirmed that the five factors were related and measured one overarching latent construct (Thompson, 2004). The higher-order factor model explained $62.651 \%$ of the variance for the EFA sample (see Table 6).

Table 6 about here 
4.2.4 Confirmatory Factor Analyses. We conducted confirmatory factor analyses on the CFA subgroup $(n 2=251)$ using AMOS software, and examined both absolute and relative model fit indexes. Comparing results to the benchmarks established by Meyers, Gamst, and Guarino (2013) allowed us to describe the goodness of fit for each model. Additionally, we referenced Model Comparison Indices, where smaller results indicate a better fit.

We first analyzed the EFA model with the higher order factor as our psychometric model, and it continued to be acceptable. Next, we tested a theory-based model. This model (described in section 3.1) was based upon how the authors coded individual items. Comparing these results (see Table 7) indicated that the psychometric-based model was a stronger fit than the one based only upon theory.

Because we aimed to create a model that was both theoretically and psychometrically sound, we examined the results of all analyses, focusing on the strongest factors across different models. We also considered the results of the parallel analysis, which had indicated that a threefactor model would be the best fit to the data. Using convergent information from all our analyses, we hypothesized that our tool should include 30 items measuring a three-factor model (Beliefs about self as a writer, beliefs about writing, and attitude towards writing). Additionally, the beliefs about self as a writer factor contained two sub-factors (self-efficacy and self-concept). Table 7 about here

As a final validity check, we considered the reliability coefficients of the final model. Both data resulted in strong reliability estimates for the individual factors and overarching scale (see Table 8).

Table 8 about here

\subsection{Discussion for Study 1: Substantive Validation}


4.3.1 Psychometrics: Convergent Results and Model of Best Fit. According to Benson (1998), a strong validation program is “typified by the prominent role theory plays” (p. 11). In the present study, we began by consulting existing research related to both writing and general academic motivation. We used this body of literature to code our items and hypothesize their relationship to one another and the overall construct of writing motivation. Next, we conducted statistical analyses (i.e., EFA, CFA) to compare rival models.

We isolated the EFA from our theoretical inquiry. Our model-of-best fit suggested that a five-factor model, with one higher-order factor, would explain the most variance in the data while aligning like-items. However, our parallel analysis provided some evidence that a threefactor model was the best fit for the data.

Finally, in our CFA, we examined both the theory and psychometrically-based models. Both yielded adequate fits to the data, with the psychometric model being a slightly stronger fit. We considered all results, including our parallel analysis, and tested a three-factor model based upon both theory and psychometrics. The results of this analysis indicated that our final model provided the strongest fit to the data (see Table 7). It also aligns with the parallel analysis conducted on the EFA data, indicating that three factors would be statistically significant. Most importantly, the 30 included items correlated logically and align with existing theory (see Appendix B).

4.3.2 SWAS Reliability. Reliability is a necessary piece of validity, because it estimates the level of measurement error in scores (Grissom \& Kim, 2012; Thompson, 2003). To establish the reliability of the scores produced by the SWAS, we examined the individual factors and overall reliability coefficients. The factor scores yielded Cronbach's $\alpha$ reliability coefficients ranging from 0.697 to 0.885 and McDonald's $\omega_{\mathrm{H}}$ scores ranging from 0.661 to 0.844 . In both 
administrations, the scores related to Writer Self-Efficacy had the lowest relative reliability coefficient ( $\alpha=0.682$ and 0.697 ). This is the factor with the fewest number of items, and as the number of items in the measure influences reliability, it is logical that it would yield the lowest reliability coefficient. Nevertheless, reliability scores are context dependent and these estimates are equal to or higher than previous researchers found for other, similar measures (e.g., Collie et al., 2016; Troia et al., 2013).

The overall reliability coefficients from this study ( $\alpha=0.936$ and 0.943$)$ indicate that over $90 \%$ of the variance in responses can be attributed to true human variance, not measurement error (Cumming, 2012). This result indicates that the SWAS produces reliable scores for both the various factors and students’ motivation for writing.

\section{Study 2: External Validation}

\subsection{Study 2 Methods}

5.1.1 Survey Administration. We administered the SWAS to a second, independent, group of participants. Students completed a paper-based version of the survey in approximately 15 minutes. We used this administration to complete the external stage of our construct validation program. In this study, we solicited parental consent and collected more information about individual students, including teacher ratings and writing samples.

5.1.2 Participants and School Context. The sample consisted of 53 students in grades six through 11 who attended a private, independent school in the same geographic area as the public middle school (see Table 9). This school, on average, served families from a high socioeconomic status and had small class sizes. It also reflected a linguistically and culturally diverse population with a student body representing over 23 different nationalities.

Table 9 about here 
5.1.3 Teacher Ratings. The English teachers provided ratings of different aspects of their students' motivation for writing. At the school, there were only two English/Language Arts teachers, and both had known most of the students for multiple years. We supplied the teachers with brief definitions of the constructs as well as a rubric for scoring. The teachers also provided a holistic rating of each student's writing skills as compared to grade level expectations, scoring them from one ("writes well below grade level”) to five (“writes well above grade level”).

5.1.4 Writing Achievement \& Productivity Measures. To measure achievement, we administered the spontaneous writing subsection of the Test of Written Language (TOWL, Hammill \& Larsen, 2009), which yields percentile scores for both contextual conventions (i.e. orthographic and grammatical conventions) and story composition (e.g., vocabulary and prose). We also wanted to examine students' writing in authentic, classroom contexts, so we collected argumentative writing samples students had completed for science class. We chose this sample because all students in the various grades had completed a similar assignment. Additionally, we anticipated that collecting writing outside of English/language arts class would reduce the threat of the John Henry effect (i.e., participants perform differently because they know their actions are being monitored; Thompson, 2006).

We first used the Rubric for Scientific Writing (RSW, Authors, 2016) to obtain a score for students’ English Composition. Three independent researchers with backgrounds in English education rated each writing sample for organization, audience, and presentation. The raters demonstrated internal consistency estimates ranging from 0.810 to 0.865 . A minimum of two raters agreed on $91.4 \%$ of organization, $82.8 \%$ of audience, and $87.1 \%$ of presentation scores. We used the average of the three raters' scores for the following analysis. 
We correlated scores from the RSW and TOWL with students' SWAS scores. We also measured the correlations between students' average number of words written for each assignment with their scores on the SWAS. Though word count is not a measure of writing quality, students who are highly motivated tend to produce more text for this low-stakes writing activity than their peers. Furthermore, word counts have been used in other studies as a measure of productivity and represent a strong predictor of writing quality (Drijbrooms, Groen, \& Verhoeven, 2017).

\subsection{Study 2 Results}

5.2.1 Model of Best Fit. Using the model of best fit from Study 1, we ran a CFA of the SWAS administration from Study $2(n=53)$. Cronbach's $\alpha$ and McDonald's $\omega_{\mathrm{H}}$ scores are consistent with the results of Study 1, indicating that across diverse samples the instrument yields reliable scores (see Table 10).

Table 10 about here

5.2.2 Correlations of Teacher Ratings and SWAS Factors. We calculated the Pearson's $r$ two-tailed correlations between the teacher ratings and student self-reported scores on the SWAS (see Table 11). All correlations were statistically significant at the .01 level. This indicates that measures of individual factors on the SWAS matched teacher perceptions.

Table 11 about here

5.2.3 Correlations of Writing Achievement and SWAS Factors. We calculated the Pearson's $r$ two-tailed correlations between the various measures of writing achievement and student self-reported scores on the SWAS (see Table 12). Similar to the ELA teacher ratings, students' self-reported writing motivation had a small, but statistically significant, relationship with their writing achievement. 
Table 12 about here

\subsection{Discussion for Study 2: External Validation}

To establish external validity, we examined how students’ self-reported scores correlated with observed measures of writing motivation and direct measures of writing skill. In terms of the latter, students' scores on both contrived (i.e., TOWL) and authentic (i.e. RSW) writing tasks yielded statistically significant correlations with their scores on the SWAS. Furthermore, students who reported higher levels of motivation produced more written text. The small size of this group ( $n=53)$, combined with the statistically significant findings, indicate that these modest correlations are likely real effects and not a result of sampling error (Thompson, 2006).

Students' self-reported data was also highly correlated with teachers’ perceptions of their students. While the limited number of related studies measuring this relationship in writing prohibits direct comparison, we did examine existing research related to other aspects of literacy. For instance, Guthrie and colleagues’ (2007) correlations of student reading motivation (as demonstrated through coded interviews) with teacher ratings ranged from 0.17 to 0.77 . Additionally, teachers' rating of student motivation yielded an average correlation with survey data of 0.36 . In contrast, the correlations we found between teacher ratings and student selfreport on the SWAS yielded much less variance than and all correlations were statistically significant (ranging from 0.349 to 0.529 ). That teacher perceptions more closely matched student responses may be due to the expressive nature of writing compared to reading - teachers have both behavioral cues and direct artifacts from which to infer student motivation. Furthermore, due to the small school setting and having students across multiple years, these teachers may have been particularly well qualified informants.

\section{General Discussion \& Model of Writing Motivation}


Regarding our overarching theoretical question, the model that best fit the data is based upon a combination of theory and psychometrics (see Figure 1) with attitudes and belief system representing two unique contributions to motivation, which was predicted by our review of the literature.

Figure 1 about here

This model overlaps with aspects of Conradi and colleagues’ (2014) proposed hierarchy of reading motivation-related constructs. Their hierarchy conceptualized two categories related to beliefs - those about the self and those specific to the task. Furthermore, subsumed within beliefs about the self were self-efficacy and self-concept. Similarly, our model suggests that selfbeliefs as a writer are comprised of students’ self-concept and self-efficacy.

Moreover, the two factors related to beliefs align not only with the hierarchy proposed by Conradi and colleagues, but also with constructs described by Expectancy-Value Theory (EVT). According to EVT scholars, human behavior can be explained by a person's beliefs about their ability to be successful at a task (i.e., expectancies) and the value they place upon that task (Eccles \& Wigfield, 2002). Writer Self-Beliefs are representative of the former, and beliefs about writing specifically addresses the value placed upon the task.

Finally, a recent systematic review of related literature revealed that the term writing attitudes, which we conceptualized as students’ pre-dispositions towards writing, has been used to define a variety of constructs over the past 25 years (Ekholm et al., 2017). However, our analyses indicate that attitude is a separate construct from students' beliefs towards writing and themselves as writers. In reviewing our analysis, the factor that we identified as attitude in the final model was the most stable. That is, the majority of items measuring attitude held together both in our theoretical coding and in the factor analyses. While strongly correlated with other 
factors, we argue for its inclusion as a separate factor based upon both theoretical and psychometric evidence.

It is also important to note that we intentionally surveyed divergent samples and found consistent reliability scores. First, in Study 1 we administered the SWAS to public school children, many of whom were from low SES households and/or were also English Language Learners (ELLs). In Study 2, we administered the SWAS to children attending a private school, many of whom were from high SES households and international backgrounds. The stability of reliability across different populations indicates that the instrument is appropriate for diverse adolescent populations. Such results are particularly essential given the growing diversity of school populations.

\section{Limitations \& Future Directions}

Despite these rigorous validation procedures, we recognize that limitations remain. Unfortunately, we were not able to collect data about students in Study 1 and therefore could not analyze class-level and individual characteristics, such as language-learning status or gifted and talented enrollment. In particular, future research should conduct measurement invariance analyses to assess whether the constructs of the SWAS function equivalently across gender and skill level. Additionally, we readily admit that the two populations of students are not directly comparable. However, independently each population yielded validity evidence for the SWAS. Therefore, we argue that their differences actually suggest that scores from the SWAS would be valid for a wide range of students.

We also collected all data for this study from one geographic region. Thus, similar data must be collected from a more geographically diverse sample before generalizations regarding motivational trends can be made. Additionally, we only utilized concurrent measures for validity, 
and longitudinal measures would add to our understanding of writing motivation. Such longitudinal data would also allow researchers to honor the fact that motivation tends to be diachronic, changing over time and through experiences (Dörnyei, 2000).

We also acknowledge that while we were able to validate that the SWAS measures specific motivational constructs, motivation is multifaceted, and we have certainly not captured all its complexities in this measure. As is endemic to any scale development process, to achieve parsimony, we had to sacrifice complexity. However, we maintain that the final model is directly supported by our theoretical review. The removed items did not represent additional constructs, but instead represented theoretically ambiguous items.

However, this does not mean that we included all potential constructs for motivation. Engagement, a related construct to motivation has been included in previous scales (e.g., Collie et al, 2016). Yet we maintain that engagement represents an emotional or behavioral state and recent work provides evidence that students' engagement in class is measured more validly by online/in situation measures than a one-time survey (e.g., see Pöysä et al., 2018). Furthermore, recent revisions to the EVT model have included another factor - costs - that describes the opportunities lost because of engaging in an activity (Flake, Barron, Hulleman, McCoach, \& Welsh, 2015). While our model does not address these potential costs, future researchers can explore their possible contributions.

Finally, the validation of the SWAS offers multiple directions for future researchers. Much as McKenna and colleagues have established with reading (McKenna et al, 2012; McKenna \& Kear, 1990), future researchers can examine how writing motivation shifts through the grades. With further validation work at lower grade levels, the field may also be able to track what happens to writing motivation as children advance from elementary to secondary schools. 
Such work would also allow for the analysis of multi-level models examining the impact of classroom level variables on students' motivation to write.

\section{Conclusions}

While teachers certainly agree that an adolescents' motivation for writing greatly enhances (or reduces) their growth, such discussions of writing motivation has often remained mired at the level of anecdote. Therefore, to make the previously "intangible" into a tangible construct that we can more systematically work to improve, we first need tools to help us measure these constructs. We need to move writing motivation from anecdote to science.

To develop such a measure, especially for an affective domain that can be difficult to capture quantitatively, it is important to conduct a strong validation program, because it is only through this process that the scores have meaning (Benson, 1998). We accomplished this for the SWAS by establishing the substantive, structural, and external components. Following these procedures, we established that the SWAS is a valid measure of adolescent students' writing motivation. Additionally, through this process, we add to the theoretical base by proposing a new multi-dimensional model of writing motivation grounded in Expectancy Value Theory (EVT, Eccles \& Wigfield, 2002) and Theory of Attitude (Fishbein \& Ajzen, 1975)

The SWAS is a tool that teachers and researchers can use to assess student writing motivation during the pivotal adolescent years. For example, teachers may use the SWAS to identify students at risk for writing failure while educational researchers, with cognitive instructional goals, can monitor how their interventions interact with students' writing motivation. To facilitate meaningful change, future research needs to identify intervention and instructional practices that lead to both higher levels of motivation and achievement. As policy makers often pin their hopes on high stakes, achievement testing, teachers increasingly find 
themselves with dispirited and disinterested students. Though hardly a solution in itself, the SWAS can be used as a first step towards recognizing and creating an environment where students value writing and see themselves as capable writers. 


\section{References}

Authors, 2016, 2017

Applebee, A. N., \& Langer, J. A. (2009). What is happening in the teaching of writing? The English Journal, 98(5), 18-28.

Benson, J. (1998). Developing a strong program of construct validation: A test anxiety example. Educational Measurement: Issues and Practice, 17(1), 10-17.

Bong, M., \& Skaalvik, E. M, (2003). Academic self-concept and self-efficacy: How different are they really? Educational Psychology Review, 15(1), 1-40.

Brackett, M. A., Reyes, M. R., Rivers, S. E., Elbertson, N. A., \& Salovey, P. (2012). Assessing teachers’ beliefs about social and emotional learning. Journal of Psychoeducational Assessment, 30(3), 219-236. doi: 10.1177/0734282911424879

Bruning, R., Dempsey, M., Kauffman, D. F., McCKim, C., \& Zumbrunn, S. (2013). Examining dimensions of self-efficacy for writing. Educational Psychology, 105(1), 25-38.

Bruning, R., \& Horn, C. (2000). Developing motivation to write. Educational Psychologist, 25(1), 25-37.

Bruning, R. H., \& Kauffman, D. F. (2016). Self-efficacy beliefs and motivation in writing development. In C. A. MacArtur, S. Graham, \& J. Fitzgerald (eds.) Handbook of writing research ( $2^{\text {nd }}$ ed) (pp. 160-173). New York, NY: The Guildford Press.

Clearly, L. M (1996). I think I know what my teachers want now: Gender and writing motivation. English Journal, 85(1), 50-57.

Collie, R. J., Martin, A. J., \& Curwood, J. S. (2016). Multidimensional motivation and engagement for writing: Construct validation with a sample of boys. Educational Psychology, 36(4), 771-791. 
Conradi, K. Jang, B. G., \& McKenna, M. C. (2014). Motivation terminology in reading research: A conceptual review. Educational Psychology Review, 26, 127-164. doi: 10.1007/s10648-013-9245-z

Cumming, G. (2012). Understanding the new statistics: Effect sizes, confidence intervals, and meta-analysis. New York, NY: Routledge.

Deci, E. L., Vallerand, R. J., Pelletier, L. G., \& Ryan, R. M. (1991). Motivation and education: The self-determination perspective. Educational Psychologist, 26(3), 325-346.

Dörnyei, Z. (2000). Motivation in action: Towards a process-oriented conceptualization of student motivation. British Journal of Educational Psychology, 70, 519-538.

Drijbooms, E., Groen, M. A., \& Verhoeven, L. (2017). How executive functions predict development in syntactic complexity of narrative writing in the upper elementary grades. Reading and Writing, 30, 209-231. doi: 10.1007/s11145-016-9670-8

Eccles, J. S., Alder, T.E., Futterman, R., Goff, S. B., Kaczala, C. M., Meece, J. L., \& Midgley, C. (1983). Expectancies, values, and academic behaviors. In J. T. Spence (Ed.), Achievement and achievement motives: Psychological and sociological approaches (pp. 75-146). San Francisco, CA.: W. H. Freeman and Company.

Eccles, J. S., \& Hulleman, C. S. (2017, April). Expectancy-Value Theory. Paper presented at the meeting of the American Educational Research Association, San Antonio, TX.

Eccles, J. S., \& Wigfield, A. (2002). Motivation, beliefs, values, and goals. Annual Review of Psychology, 53, 109-132.

Ekholm, E., Zumbrunn, S., \& DeBusk-Lane, M. (2017). Clarifying an elusive construct: A systematic review of writing attitudes. Educational Psychology Review, 30(3), 827-856. doi: 10.1007/s10648-017-9423-5 
Fishbein, M. \& Ajzen, I. (1975). Belief, attitude, intention and behavior. Reading, MA: AddisonWesley Publishing Company.

Flake, J. K., Barron K. E., Hulleman, C., McCoach, B. D., \& Welsh, M. E. (2015). Measuring cost: The forgotten component of expectancy-value theory. Contemporary Educational Psychology, 41, 232-244. doi: 10.1016/j.cedpsych.2015.03.002

Frankel, K. K., Becker, B. L., Rowe, M. W., \& Pearson, P. D. (2016). From “what is reading?” to “what is literacy?”. Journal of Education, 196(3), 7-17. doi: $10.1177 / 00205741619600303$

Gillis, V. (2014). Disciplinary literacy: Adapt not adopt. Journal of Adolescent \& Adult Literacy, 57(8), 614-623. doi: 10.1002/jaal.301

Graham, S. (2018). A writer(s) within community model of writing. In C. Bazerman, V. Berninger, D. Brandt, S. Graham, J. Langer, S. Murphy, P. Matsuda, D. Rowe, \& M. Schleppegrell, (Eds.), The lifespan development of writing (pp. 272-325). Urbana, IL: National Council of English.

Graham, S., Kiuhara, S. A., Harris, K. R., \& Fishman, E. J. (2017). The relationship among strategic writing behavior, writing motivation, and writing performance with young, developing writers. The Elementary School Journal, 118(1), 82-104.

Graham, S., \& Harris, K. R. (2009). Almost 30 years of writing research: Making sense of it all with The Wrath of Khan. Learning Disabilities Research, 24(2), 58-68.

Graham, S., \& Harris, K. R. (2012). The role of strategies, knowledge, will, and skills in a 30 year program of research (with homage to Hayes, Fayol, and Boscolo). In V. Berninger (Ed.), Past, present, and future contributions of cognitive writing research to cognitive psychology (pp. 177-196). London: Psychology Press. 
Graham, S. \& Perin, D. (2007). A meta-analysis of writing instruction for adolescent students. Journal of Educational Psychology, 99(3), 445-476. doi: 10.1037/002-0663.993445

Grissom, R. J., \& Kim, J. J. (2012). Effect sizes for research: Univariate and multivariate applications ( $2^{\text {nd }}$ ed.). New York, NY: Routledge.

Guthrie, J. T., Hoa, A. L. W., Wigfield, A., Tonks, S. M., Humenick, N. M., \& Littles, E. (2007). Reading motivation and reading comprehension growth in the later elementary years. Contemporary Educational Psychology, 32, 282-313. doi:

10.1016/j.cedpsych.2006.05.004

Guthrie, J. T., Hoa, L. W., Wigfield, A., Tonks, S. M., \& Perencevich, K. C. (2006). From spark to fire: Can situational reading interest lead to long-term reading motivation?. Reading Research and Instruction, 45(2), 91-117.

Hall, A. H. (2016). Examining shifts in preservice teachers' beliefs and attitudes toward writing instruction. Journal of Early Childhood Teacher Education, 37(2), 142-156.

Hammill, D. D., \& Larsen, S. C. (2009). Test of Written Language - Fourth Edition. (Measurement Instrument)

Hattie, J. (2009). Visible learning: A synthesis of over 800 meta-analyses relating to achievement. New York, NY: Routledge.

Henk, W. A., Bottomley, D. M., Melnick, S. A., Truscott, D. M., Finke, J. A., Rickelman, R. J., Marinak, B. A., \& Helfeldt, J. P. (1997). The writer self-perception scale: A cumulative validation update. In Inquiries in literacy theory and practice: Forty-sixth yearbook of the National Reading Conference (555-563). Chicago, IL: National Reading Conference. 
Henk, W. A., \& Melnick, S. A. (1995). The Reader Self-Perception Scale (RSPS): A new tool for measuring how children feel about themselves as readers. The Reading Teacher, 48(6). 470-482.

Johnston, P. \& Costello, P. (2005). Principles for literacy assessment. Reading Research Quarterly, 40, 256-267. doi:10.1598/RRQ.40.2.6

Katz, I., \& Assor, A. (2007). When choice motivates and when it does not. Educational Psychology Review, 19, 429-442. doi: 10.1007/s10648-006-9027-y

Kear, D. J., Coffman, G. A., McKenna, M. C., \& Ambrosio, A. L. (2000). Measuring attitude toward writing: A new tool for teachers. The Reading Teacher, 54, 10-23.

Locke, T., \& Johnston, M. (2016). Developing an individual and collective self-efficacy scale for the teaching of writing in high schools. Assessing Writing, 28, 1-14.

Mason, L. H. (2004). Explicit self-regulated strategy development versus reciprocal questioning: Effects on expository reading comprehension among struggling readers. Journal of Educational Psychology, 96(2), 283-296.

Mathewson, G. C. (1994). Model of attitude influence upon reading and learning to read. In R. B. Ruddell, M. R. Ruddel, \& H. Singer (Eds.), Theoretical models and processes of reading (4 ${ }^{\text {th }}$ ed., pp. 1131-1161). Newark, DE: International Reading Association.

McKenna, M. C., Conradi, K., Lawrence, C., Jang, B. G., \& Meyer, J. P. (2012). Reading attitudes of middle school students: Results of a U.S. survey. Reading Research Quarterly, 47(3), 283-306.

McKenna, M. C., \& Kear, D. J. (1990). Measuring attitude towards reading: A new tool for teachers. The Reading Teacher, 43(9), 626-639. 
Meyers, L. S., Gamst, G., \& Guarino, A. J. (2013). Applied multivariate research: Design and interpretation ( $2^{\text {nd }}$ ed.). Los Angeles, CA: SAGE publications.

Myers, J., Scales, R. Q., Grisham, D. L., Wolsey, T. D., Dismuke, S., Smetana, L., Yoder, K. K., Ikpeze, C., Ganske, K., \& Martin, S. (2016). What about writing? A national exploratory study of writing instruction in teacher preparation programs. Literacy Research \& Instruction, 55(4), 309-330. doi: 10.1080/19388071.2016.1198442

National Center for Education Statistics (2012). The Nation's Report Card: Writing 2011 (NCES 2012-470). Institute of Education Sciences, U.S. Department of Education, Washington, D.C.

Pajares, F. (2003). Self-efficacy beliefs, motivation, and achievement in writing: A review of the literature. Reading \& Writing Quarterly, 19, 139-158. doi: 10.1080/10573560308222

Pajares, F. (2007). Empirical properties of a scale to assess writing self-efficacy in school contexts. Measurement and Evaluation in Counseling and Development, 39, 239-249. doi: 10.1080/07481756.2007.11909801

Pajares, F. \& Valiante, G. (2006). Self-efficacy beliefs and motivation in writing development. In C. A. MacArthur, S. Graham, \& J. Fitzgerald (eds) Handbook of writing research (pp. 158-170). New York, NY: Guilford.

Pöysä, S., Vasalampi, K., Muotka, J., Lerkkanen, M. K., Poikkeus, A. M., \& Nurmi, J. E. (2018). Variation in situation-specific engagement among lower secondary school students. Learning and Instruction, 53, 64-73.

Prior, P. (2006). A sociocultural theory of writing. In C. A. MacArthur, S. Graham, \& J. Fitzgerald (eds) Handbook of writing research (pp. 54-66). New York, NY: Guilford. 
Schaefer, M. B., Malu, K. F., \& Yoon, B. (2016). An historical overview of the middle school movement, 1963-2015. RMLE Online, 39(5), 1-27. doi: 10.1080/19404476.2016.1165036

Shanahan, T., \& Shanahan, C. (2008). Teaching disciplinary literacy to adolescents: Rethinking content-area literacy. Harvard Educational Review, 78(1), 40-59.

Shanahan, T., \& Shanahan, C. (2012). What is disciplinary literacy and why does it matter? Top Language Disorders, 32(1), 7-18.

Steinmayer, R., \& Spinath, B. (2009). The importance of motivation as a predictor of school achievement. Learning and Individual Differences, 19, 80-90.

Thompson, B. (2003). Understanding reliability and coefficient alpha, really. In B. Thompson, (Ed.). (2003). Score reliability: Contemporary thinking on reliability issues. Newbury Park, CA: Sage.

Thompson, B. (2004). Exploratory and confirmatory factor analysis. Washington, DC: American Psychological Association.

Thompson, B. (2006). Foundations of behavioral statistics: An insight-based approach. New York: Guilford.

Troia, G. A., Harbaugh, A. G., Shankland, R. K., Wolbers, K. A., \& Lawrence, A. M. (2013). Relationships between writing motivation, writing activity, and writing performance: Effects of grade, sex, and ability. Reading and Writing, 26, 17-44.

Troia, G. A., \& Maddox, M. E. (2004). Writing instruction in middle schools: Special and general education teachers share their views and voice their concerns. Exceptionality, 12(1), 19-37. doi: 10.1207/s15327035ex1201_3 
Villalón, R., Mateos, M. \& Cuevas, I. (2013). High school boys’ and girls’ writing conceptions and writing self-efficacy beliefs: What is their role in writing performance? Educational Psychology, 35(6), 653-674. doi: 10.1080/01443410.2013.836157

Vygotsky, L. S. (1978). Mind in Society: The development of higher psychological processes. Boston, MA: Harvard University Press.

Washburn, E. Sielaff, C., \& Golden, K. (2016). The use of a cognitive strategy to support argument-based writing in a ninth grade social studies classroom. Literacy Research and Instruction, 55(4), 353-374. doi: 10.1080/19388071.2016.1165319

Webb. A. F., Vandiver, B. J., \& Jeung, S. (2016). Does completing an enriched writing course improve writing self-efficacy of talented secondary students? Gifted Child Quarterly, 60(1), 47-62. doi: 10.1177/0016986215605359

Wigfield, A., \& Guthrie, J.T. (1995) Dimensions of children's motivations of reading: An initial study (Research Rep. No. 34). Athens, GA: National Reading Research Center.

Zumbrunn, S., Marrs, S., \& Mewborn, C. (2016). Toward a better understanding of student perceptions of writing feedback: A mixed methods study. Reading \& writing, 29, 349370. doi: 10.1007/s11145-015-9599-3 


\section{Appendix A}

\section{Structure Coefficients for Psychometric Model-of-Best-Fit}

\begin{tabular}{|c|c|c|c|c|c|}
\hline Item & Factor 1 & Factor 2 & Factor 3 & Factor 4 & Factor 5 \\
\hline I would rather write a story than do homework & .743 & -.074 & .054 & .102 & .037 \\
\hline I like writing long stories or reports at school & .703 & .295 & 116 & .043 & .201 \\
\hline I can write good papers because writing is easy for me. & .691 & .309 & 140 & .347 & .067 \\
\hline I like to write. & .680 & .401 & .121 & .112 & .293 \\
\hline I think it would be fun to be an author who writes books & .669 & .142 & .283 & -.043 & .142 \\
\hline Overall, I have positive feelings about writing. & .645 & .432 & .151 & .228 & .251 \\
\hline Writing can be a lot of fun. & .622 & .411 & .278 & .046 & .222 \\
\hline In comparison to my other school subjects, I am best at writing & .593 & .204 & -.008 & .158 & .355 \\
\hline When writing it's easy for me to think of the right words & .586 & -.014 & .244 & .206 & -.065 \\
\hline Most of my writing is for fun & .560 & .270 & .217 & -.061 & .082 \\
\hline $\begin{array}{l}\text { I think it would be fun to have a job as a writer for a newspaper } \\
\text { or magazine }\end{array}$ & .537 & .276 & .175 & -.038 & .066 \\
\hline $\begin{array}{l}\text { I am confident in writing for many purposes (persuade, inform, } \\
\text { entertain, or express). }\end{array}$ & .496 & .444 & .115 & .366 & .137 \\
\hline When I write a paper, it is easy for me to come up with ideas & .477 & .087 & .380 & 209 & .138 \\
\hline Finishing every writing assignment is very important to me & .172 & .731 & .108 & .056 & .090 \\
\hline $\begin{array}{l}\text { I feel most successful if I see that my writing has really } \\
\text { improved. }\end{array}$ & .221 & .709 & 184 & .102 & -.149 \\
\hline $\begin{array}{l}\text { I think it would be great to become an even better writer than I } \\
\text { already am }\end{array}$ & .293 & .683 & .155 & .109 & .092 \\
\hline $\begin{array}{c}\text { When I get a good grade on a paper, it is because I tried really } \\
\text { hard. }\end{array}$ & .041 & .660 & .060 & .142 & .075 \\
\hline Writing helps me learn & .297 & .627 & .083 & -.005 & .211 \\
\hline I believe it is very important to be a good writer & .372 & .617 & .133 & .083 & .044 \\
\hline $\begin{array}{l}\text { I don't mind when the teacher asks me to go back and change } \\
\text { some of my writing }\end{array}$ & .035 & .554 & .384 & .115 & .249 \\
\hline $\begin{array}{l}\text { I enjoy checking my writing to make sure the words I have } \\
\text { written are spelled correctly }\end{array}$ & .050 & .521 & .486 & .180 & .208 \\
\hline I feel confident sharing my writing with my friends. & .311 & .120 & .729 & .198 & .012 \\
\hline I like when my classmates read something I wrote & .280 & .149 & .669 & .152 & .029 \\
\hline I like to help my friends with their writing schoolwork & .285 & .381 & .581 & -.097 & .216 \\
\hline When I'm proofreading, it's easy for me to catch my mistakes. & .148 & .276 & .433 & .127 & .092 \\
\hline $\begin{array}{c}\text { I don't get good grades in writing because I’m just not smart } \\
\text { enough* }\end{array}$ & .107 & .038 & .162 & .705 & -.084 \\
\hline $\begin{array}{c}\text { When I get a good grade on a writing assignment, it's because } \\
\text { I got lucky* }\end{array}$ & -.002 & .083 & .090 & 642 & 317 \\
\hline $\begin{array}{l}\text { When my class is asked to write an essay, report, or story, } \\
\text { mine is one of the best. }\end{array}$ & .439 & .256 & .016 & .558 & .192 \\
\hline I feel confident in my overall writing abilities. & .519 & .352 & .172 & .456 & -.012 \\
\hline $\begin{array}{l}\text { When writing, it's easy for me to decide what goes 1st, 2nd, } \\
\text { 3rd, and so on }\end{array}$ & 207 & .396 & .314 & .425 & .056 \\
\hline I know that I will do well in writing this year & .495 & .377 & .243 & .418 & .059 \\
\hline I do as little writing as possible for school* & .098 & .181 & .052 & -.029 & .747 \\
\hline I try to not have any writing homework.* & .091 & .044 & .051 & .122 & .717 \\
\hline I wish we wrote less in school* & .336 & -.002 & .164 & .138 & .642 \\
\hline I write mostly because I have to for school.* & .177 & -.035 & .171 & -.119 & 618 \\
\hline I don't like having to rewrite my paper* & .001 & .185 & -.056 & .166 & .540 \\
\hline
\end{tabular}

\footnotetext{
* Item reverse coded for analysis
} 


\section{Appendix B}

\section{Structure Coefficients for Final Model}

\begin{tabular}{|c|c|c|}
\hline Item & Factor & $\begin{array}{l}\text { Structure } \\
\text { Coefficient }\end{array}$ \\
\hline I don’t like having to rewrite my paper* & Attitude & .227 \\
\hline I like to write. & Attitude & .845 \\
\hline I like writing long stories or reports at school & Attitude & .734 \\
\hline I think it would be fun to be an author who writes books & Attitude & .640 \\
\hline I think it would be fun to have a job as a writer for a newspaper or magazine & Attitude & .564 \\
\hline I wish we wrote less in school* & Attitude & .501 \\
\hline I would rather write a story than do homework & Attitude & .477 \\
\hline Overall, I have positive feelings about writing. & Attitude & .840 \\
\hline Writing can be a lot of fun. & Attitude & .814 \\
\hline Finishing every writing assignment is very important to me & Beliefs about Writing & .668 \\
\hline I believe it is very important to be a good writer & Beliefs about Writing & .729 \\
\hline $\begin{array}{l}\text { I don't mind when the teacher asks me to go back and change some of my } \\
\text { writing }\end{array}$ & Beliefs about Writing & .563 \\
\hline $\begin{array}{l}\text { I enjoy checking my writing to make sure the words I have written are spelled } \\
\text { correctly }\end{array}$ & Beliefs about Writing & .591 \\
\hline I feel most successful if I see that my writing has really improved. & Beliefs about Writing & .676 \\
\hline I think it would be great to become an even better writer than I already am & Beliefs about Writing & .742 \\
\hline Writing helps me learn & Beliefs about Writing & .617 \\
\hline $\begin{array}{l}\text { I am confident in writing for many purposes (persuade, inform, entertain, or } \\
\text { express). }\end{array}$ & Self-Concept & .749 \\
\hline I can write good papers because writing is easy for me. & Self-Concept & .821 \\
\hline I don't get good grades in writing because I'm just not smart enough* & Self-Concept & .343 \\
\hline I feel confident in my overall writing abilities. & Self-Concept & .742 \\
\hline In comparison to my other school subjects, I am best at writing & Self-Concept & .587 \\
\hline When I write a paper, it is easy for me to come up with ideas & Self-Concept & .537 \\
\hline $\begin{array}{c}\text { When my class is asked to write an essay, report, or story, mine is one of the } \\
\text { best. }\end{array}$ & Self-Concept & .666 \\
\hline When writing it's easy for me to think of the right words & Self-Concept & .486 \\
\hline I feel confident sharing my writing with my friends. & Self-Efficacy & .555 \\
\hline I know that I will do well in writing this year & Self-Efficacy & .789 \\
\hline When I get a good grade on a paper, it is because I tried really hard. & Self-Efficacy & .432 \\
\hline When I get a good grade on a writing assignment, it’s because I got lucky* & Self-Efficacy & .330 \\
\hline When I'm proofreading, it's easy for me to catch my mistakes. & Self-Efficacy & .454 \\
\hline When writing, it's easy for me to decide what goes 1st, 2nd, 3rd, and so on & Self-Efficacy & .602 \\
\hline
\end{tabular}

* Item reverse coded for analysis 


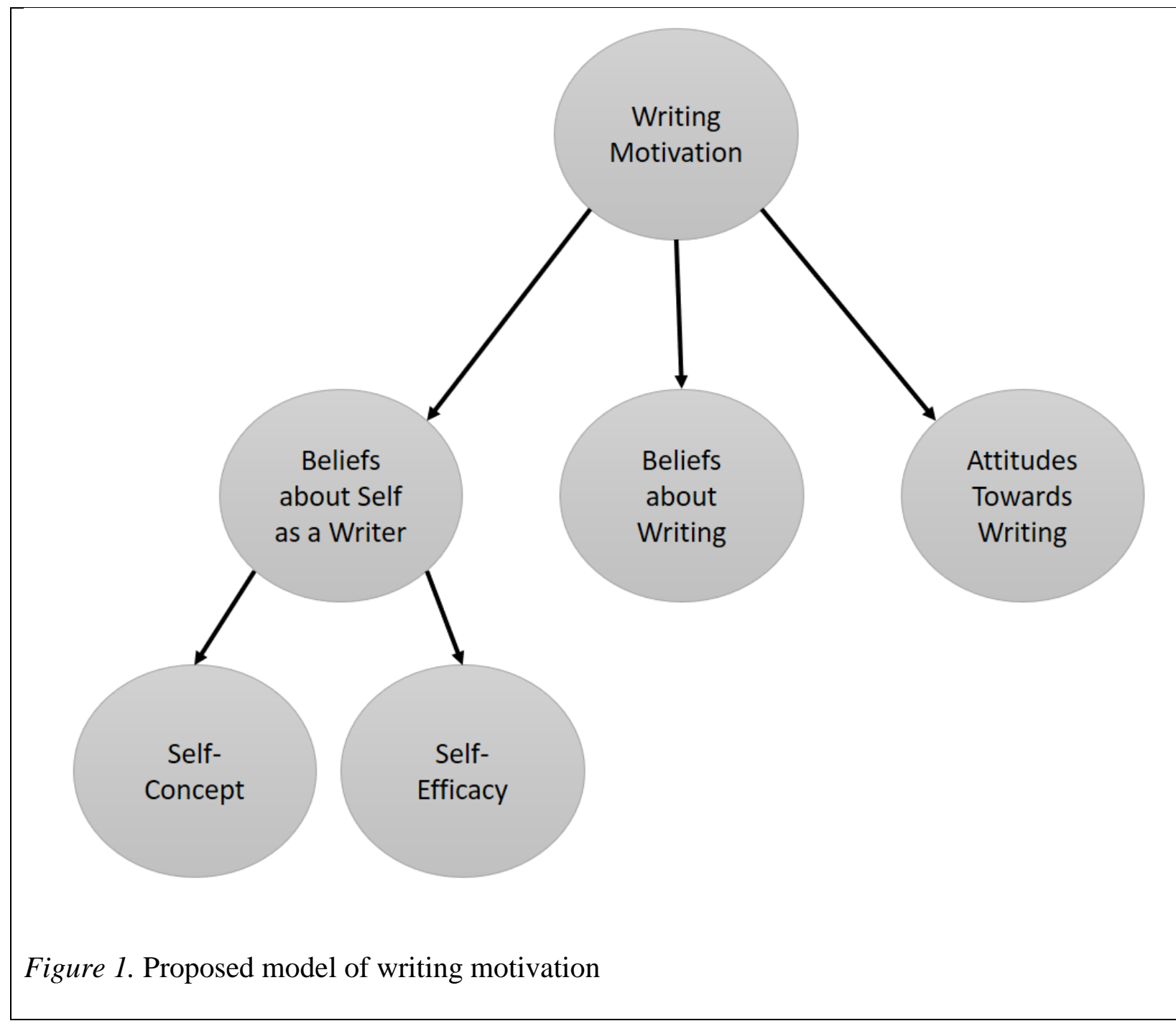


Table 1

Existing measures referenced to create survey

\begin{tabular}{ccc}
\hline Measure & Citation & Description \\
\hline $\begin{array}{c}\text { Elementary Reading Attitude } \\
\text { Survey }\end{array}$ & McKenna \& Kear (1990) & $\begin{array}{c}\text { Likert-style survey of } \\
\text { Elementary students' attitude } \\
\text { towards reading }\end{array}$ \\
\hline Reader Self-Perception Scale & Henk \& Melnick (1995) & $\begin{array}{c}\text { Likert-style survey measuring } \\
\text { students' beliefs about } \\
\text { themselves as readers }\end{array}$ \\
\hline Motivation for Reading & Wigfield \& Guthrie & $\begin{array}{c}\text { Likert-style survey of students } \\
\text { motivations for reading }\end{array}$ \\
\hline Writer Self-Perception Scale & Henk et al. (1997) & $\begin{array}{c}\text { Likert-style survey of upper- } \\
\text { elementary grade students' } \\
\text { beliefs about themselves as } \\
\text { writers }\end{array}$ \\
$\begin{array}{c}\text { Elementary Writing Attitude } \\
\text { Survey }\end{array}$ & Kear et al. (2000) & $\begin{array}{c}\text { Much like the Elementary } \\
\text { Reading Attitude Survey, but } \\
\text { rephrased to measure students' } \\
\text { attitudes towards writing }\end{array}$ \\
\hline $\begin{array}{c}\text { Scales for the Assessment of } \\
\text { Learning and Performance } \\
\text { Motivation (translated from } \\
\text { German title) }\end{array}$ & Steinmayer \& Spinath & $\begin{array}{c}\text { Likert-style scale assessing } \\
\text { affective and personality factors } \\
\text { that may impact students' } \\
\text { academic performance }\end{array}$ \\
\hline $\begin{array}{c}\text { Writing Activity and } \\
\text { Motivation Scales }\end{array}$ & Troia et al. (2013) & $\begin{array}{c}\text { Survey which measures both } \\
\text { students motivation for writing } \\
\text { and writing behaviors }\end{array}$ \\
\hline
\end{tabular}


Table 2

Participant Descriptive Information (Study 1, Group 1)

\begin{tabular}{lll}
\hline Total & 517 & Percentage \\
\hline Males & 225 & $44 \%$ \\
Females & 220 & $42 \%$ \\
Gender not reported & 72 & $14 \%$ \\
\hline $6^{\text {th }}$ Grade & 192 & $37 \%$ \\
$7^{\text {th }}$ Grade & 156 & $30 \%$ \\
$8^{\text {th }}$ Grade & 150 & $29 \%$ \\
Grade not reported & 19 & $4 \%$ \\
\hline
\end{tabular}


Table 3

Summary of EFA Models

\begin{tabular}{ccccccc}
\hline $\begin{array}{c}\text { EFA } \\
\#\end{array}$ & Description & $\begin{array}{c}\text { Number } \\
\text { of Survey } \\
\text { Items }\end{array}$ & $\begin{array}{c}\text { Number } \\
\text { of } \\
\text { Factors }\end{array}$ & $\begin{array}{c}\text { Mean items } \\
\text { per factor }\end{array}$ & $\begin{array}{c}\text { Percent } \\
\text { Variance } \\
\text { Explained }\end{array}$ & $\begin{array}{c}\text { Mean } \\
\text { Factor } \\
\text { Reliability }\end{array}$ \\
\hline 1 & Eigenvalues over 1 & 41 & 8 & $5.12(4.91)$ & 59.96 & $0.69(.194)$ \\
\hline 2 & $\begin{array}{c}\text { Repeat EFA \#1, removing items } \\
\text { with structure coefficients }<0.5\end{array}$ & 31 & 6 & $5.16(4.26)$ & 59.68 & $0.68(.194)$ \\
\hline 3 & Forced 5 factors & 41 & 5 & $8.20(5.16)$ & 52.04 & $0.78(.10)$ \\
\hline 4 & $\begin{array}{c}\text { Repeat EFA \#3, removing items } \\
\text { with structure coefficients }<0.5\end{array}$ & 30 & 5 & $6.00(4.06)$ & 58.16 & $0.74(.15)$ \\
\hline 5 & $\begin{array}{c}\text { Repeat EFA \#3, only five items } \\
\text { removed }\end{array}$ & 36 & 5 & $7.20(3.56)$ & 55.94 & $0.79(.09)$ \\
\hline
\end{tabular}

Note: When appropriate, standard deviations are displayed next to means in parenthesis 
Table 4

Factors for EFA psychometric model of best fit

\begin{tabular}{cccccc}
\hline & \multicolumn{3}{c}{ Total Variance } & McDonald's \\
Factor & Items $n$ & Eigenvalue & Explained (\%) & Cronbach's $\alpha$ & $\omega_{\mathrm{H}}$ \\
\hline 1 & 13 & 6.60 & 18.35 & 0.916 & 0.908 \\
2 & 8 & 5.23 & 14.53 & 0.846 & 0.730 \\
3 & 4 & 2.79 & 7.77 & 0.683 & 0.631 \\
4 & 6 & 2.49 & 6.93 & 0.776 & 0.712 \\
5 & 5 & 3.00 & 8.35 & 0.733 & 0.690 \\
\hline Overall Scale & 36 & & 55.94 & .944 & .900 \\
\hline
\end{tabular}


Table 5

Parallel analysis results for eigenvalues greater than one at the $95^{\text {th }}$ percentile $(n=517)$

Component Principal Components Analysis Eigenvalue $\quad$ Parallel Analysis (95 ${ }^{\text {th }}$ Percentile)

\begin{tabular}{lcc}
1 & 12.976 & 1.604 \\
2 & 1.892 & 1.511 \\
3 & 1.540 & 1.466 \\
4 & 1.345 & 1.412 \\
5 & 1.229 & 1.381 \\
6 & 1.013 & 1.340 \\
7 & 0.959 & 1.304 \\
\hline
\end{tabular}


Table 6

Higher-order factor pattern coefficient matrix (EFA model of best fit)

\begin{tabular}{ccc}
\hline First-Order Factor & Pattern Coefficient $(A)$ & $h^{2}$ \\
\hline 1 & 0.894 & 0.798 \\
2 & 0.822 & 0.675 \\
3 & 0.802 & 0.644 \\
4 & 0.837 & 0.700 \\
5 & 0.561 & 0.315 \\
\hline
\end{tabular}




\section{Table 7}

Confirmatory Factor Analyses Model Fit Indexes

\begin{tabular}{|c|c|c|c|c|c|}
\hline Model & $\chi^{2} / d f$ & RMSEA & CFI & AIC & $\mathrm{BIC}$ \\
\hline $\begin{array}{l}\text { EFA with Higher Order } \\
\text { Factor }\end{array}$ & 1.98 (good) & $\begin{array}{c}0.063 \\
\text { (acceptable) }\end{array}$ & $\begin{array}{c}0.845 \\
\text { (adequate) }\end{array}$ & 1355.304 & 1393.172 \\
\hline Theory-Based Model & $\begin{array}{c}2.85 \\
\text { (acceptable) }\end{array}$ & $\begin{array}{c}0.086 \\
\text { (borderline } \\
\text { acceptable) }\end{array}$ & $\begin{array}{l}0.710 \\
(\text { poor })\end{array}$ & 30 & 0 \\
\hline $\begin{array}{l}\text { Three-Factor, Theory and } \\
\text { psychometrically influenced }\end{array}$ & $\begin{array}{c}2.01 \\
\text { (acceptable) }\end{array}$ & $\begin{array}{c}0.064 \\
\text { (acceptable) }\end{array}$ & $\begin{array}{c}0.871 \\
\text { (adequate) }\end{array}$ & 996.404 & 1022.167 \\
\hline \multicolumn{6}{|c|}{$\begin{array}{l}\text { Notes: Target values for } \chi^{2} / d f \text { are less than } 2 \text { for good, and between } 2 \text { and } 5 \text { for acceptable. Target values for Root } \\
\text { Mean Square Error of Approximation (RMSEA) are less than .08 for acceptable, and between } .08 \text { and } .10 \text { for } \\
\text { borderline acceptable. Comparative Fit Index (CFI) target values are between } .80 \text { and } .89 \text { for adequate. Both } \\
\text { Akaike Information Criterion (AIC) and Bayesian Information Criterion (BIC) are model comparison measures, } \\
\text { with lower values indicating a stronger fit (Meyers et al., 2013) }\end{array}$} \\
\hline
\end{tabular}


Table 8

Score reliability for Study 1 SWAS administration (Final psychometric- \& theory-based model)

\begin{tabular}{ccccc}
\hline & \multicolumn{2}{c}{$n 1$} & \multicolumn{2}{c}{$n 2$} \\
\hline Factor & Cronbach's $\alpha$ & McDonald's $\omega$ & Cronbach's $\alpha$ & McDonald's $\omega$ \\
\hline Attitude Towards Writing & 0.885 & 0.844 & 0.859 & 0.814 \\
Beliefs about Self as a Writer & 0.881 & 0.843 & 0.870 & 0.837 \\
Self-Concept & 0.842 & 0.805 & 0.831 & 0.797 \\
Self-Efficacy & 0.697 & 0.661 & 0.682 & 0.653 \\
Beliefs about Writing & 0.832 & 0.721 & 0.843 & 0.730 \\
\hline Overall Reliability & 0.943 & 0.900 & 0.936 & 0.900 \\
\hline
\end{tabular}




\section{Table 9}

Participant Descriptive Information (Study 2)

\begin{tabular}{lll}
\hline Total & 53 & Percentage \\
\hline Males & 32 & $62 \%$ \\
Females & 21 & $38 \%$ \\
\hline $6^{\text {th }}$ Grade & 18 & $34 \%$ \\
$7^{\text {th }}$ Grade & 7 & $13 \%$ \\
$9^{\text {th }}$ Grade & 1 & $2 \%$ \\
$10^{\text {th }}$ Grade & 13 & $25 \%$ \\
$11^{\text {th }}$ Grade & 14 & $26 \%$ \\
\hline
\end{tabular}


Table 10

Score reliability for Study 2 SWAS administration $(n=53)$

\begin{tabular}{|c|c|c|}
\hline Factor & Cronbach's $\alpha$ & McDonald's $\omega$ \\
\hline Attitude Towards Writing & 0.860 & 0.814 \\
\hline Beliefs about self as a Writer & 0.910 & 0.729 \\
\hline Self-Concept & 0.909 & 0.807 \\
\hline Self-Efficacy & 0.679 & 0.651 \\
\hline Writing Beliefs & 0.862 & 0.759 \\
\hline Overall Reliability & 0.942 & 0.900 \\
\hline
\end{tabular}


Table 11

Correlations between student self-report on SWAS and teacher ratings

\begin{tabular}{cccc}
\hline & \multicolumn{3}{c}{ Teacher Ratings } \\
\cline { 2 - 4 } SWAS Factors & Attitude towards Writing & Self-Confidence & Self-Efficacy \\
\hline Attitude Towards Writing & $0.453^{*}$ & $0.349^{*}$ & $0.368^{*}$ \\
Beliefs about self as a Writer & $0.471^{*}$ & $0.515^{*}$ & $0.436^{*}$ \\
Self-Concept & $0.467^{*}$ & $0.522^{*}$ & $0.442^{*}$ \\
Self-Efficacy & $0.418^{*}$ & $0.439^{*}$ & $0.372^{*}$ \\
Writing Beliefs & $0.539^{*}$ & $0.398^{*}$ & $0.482^{*}$ \\
\hline Overall Motivation & $0.529^{*}$ & $0.475^{*}$ & $0.467^{*}$ \\
\hline
\end{tabular}

* Correlation is significant at the .01 level (2-tailed) 
Table 12

Correlations between student self-reported scores on SWAS and writing achievement

\begin{tabular}{cccccc}
\hline & $\begin{array}{c}\text { TOWL } \\
\text { Contextual } \\
\text { SWAS Factors }\end{array}$ & $\begin{array}{c}\text { TOWL } \\
\text { Conventions }\end{array}$ & $\begin{array}{c}\text { RSW } \\
\text { Composition }\end{array}$ & $\begin{array}{c}\text { Teacher } \\
\text { Complish } \\
\text { Ratings of } \\
\text { Writing Skills }\end{array}$ & $\begin{array}{c}\text { Average \# } \\
\text { of Words }\end{array}$ \\
\hline Attitude Towards Writing & $0.340^{*}$ & $0.317^{*}$ & $0.342^{*}$ & $0.320^{*}$ & $0.446^{*}$ \\
Beliefs about self as a Writer & $0.381^{* *}$ & $0.429^{* *}$ & $0.420^{* *}$ & $0.535^{* *}$ & $0.324^{*}$ \\
Self-Concept & $0.391^{* *}$ & $0.433^{* *}$ & $0.452^{* *}$ & $0.574^{* *}$ & $0.295^{*}$ \\
Self-Efficacy & $0.309^{*}$ & $0.261^{*}$ & $0.307^{*}$ & $0.403^{* *}$ & $0.332^{*}$ \\
Writing Beliefs & $0.407^{* *}$ & $0.355^{*}$ & $0.387^{*}$ & $0.336^{*}$ & $0.342^{*}$ \\
\hline Overall Motivation & $0.419^{* *}$ & $0.420^{* *}$ & $0.429^{* *}$ & $0.457^{* *}$ & $0.410^{* *}$ \\
\hline
\end{tabular}

* Correlation is significant at the .05 level (2-tailed)

** Correlation is significant at the .01 level (2-tailed) 